\title{
Front Matter: Volume 11376
}

, "Front Matter: Volume 11376," Proc. SPIE 11376, Active and Passive Smart Structures and Integrated Systems XIV, 1137601 (21 May 2020); doi:

$10.1117 / 12.2572625$

SPIE. Event: SPIE Smart Structures + Nondestructive Evaluation, 2020, Online Only 


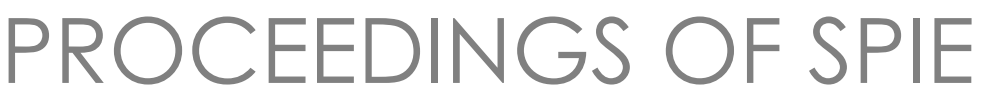

\title{
Active and Passive Smart Structures and Integrated Systems XIV
}

\author{
Jae-Hung Han \\ Gang Wang \\ Shima Shahab \\ Editors
}

27 April - 8 May 2020

Online Only, United States

Sponsored by

SPIE

Cooperating Organizations

Jet Propulsion Laboratory (United States)

Published by

SPIE 
The papers in this volume were part of the technical conference cited on the cover and title page. Papers were selected and subject to review by the editors and conference program committee. Some conference presentations may not be available for publication. Additional papers and presentation recordings may be available online in the SPIE Digital Library at SPIEDigitalLibrary.org.

The papers reflect the work and thoughts of the authors and are published herein as submitted. The publisher is not responsible for the validity of the information or for any outcomes resulting from reliance thereon.

Please use the following format to cite material from these proceedings:

Author(s), "Title of Paper," in Active and Passive Smart Structures and Integrated Systems XIV, edited by Jae-Hung Han, Gang Wang, Shima Shahab, Proceedings of SPIE Vol. 11376 (SPIE, Bellingham, WA, 2020) Seven-digit Article CID Number.

ISSN: 0277-786X

ISSN: 1996-756X (electronic)

ISBN: 9781510635296

ISBN: 9781510635302 (electronic)

Published by

SPIE

P.O. Box 10, Bellingham, Washington 98227-0010 USA

Telephone +1 3606763290 (Pacific Time) · Fax +1 3606471445

SPIE.org

Copyright (c) 2020, Society of Photo-Optical Instrumentation Engineers.

Copying of material in this book for internal or personal use, or for the internal or personal use of specific clients, beyond the fair use provisions granted by the U.S. Copyright Law is authorized by SPIE subject to payment of copying fees. The Transactional Reporting Service base fee for this volume is $\$ 21.00$ per article (or portion thereof), which should be paid directly to the Copyright Clearance Center (CCC), 222 Rosewood Drive, Danvers, MA 01923. Payment may also be made electronically through CCC Online at copyright.com. Other copying for republication, resale, advertising or promotion, or any form of systematic or multiple reproduction of any material in this book is prohibited except with permission in writing from the publisher. The CCC fee code is $0277-$ $786 \times / 20 / \$ 21.00$.

Printed in the United States of America by Curran Associates, Inc., under license from SPIE.

Publication of record for individual papers is online in the SPIE Digital Library.

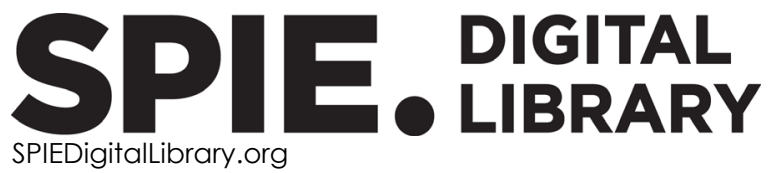

Paper Numbering: Proceedings of SPIE follow an e-First publication model. A unique citation identifier (CID) number is assigned to each article at the time of publication. Utilization of CIDs allows articles to be fully citable as soon as they are published online, and connects the same identifier to all online and print versions of the publication. SPIE uses a seven-digit CID article numbering system structured as follows:

- The first five digits correspond to the SPIE volume number.

- The last two digits indicate publication order within the volume using a Base 36 numbering system employing both numerals and letters. These two-number sets start with $00,01,02,03,04$, 05, 06, 07, 08, 09, OA, OB ... 0Z, followed by 10-1Z, 20-2Z, etc. The CID Number appears on each page of the manuscript. 


\section{Contents}

ENERGY HARVESTING I: FLOW/STRUCTURE INTERACTION

1137602 Coherent voltage beat distributions in the signals from piezoelectric energy harvesters in turbulent flow [11376-1]

1137603 A bistable galloping energy harvester for enhanced concurrent wind and base vibration energy harvesting [11376-2]

1137605 Circuit integration and road test of self tuning stochastic resonance energy harvesters for smart tire [11376-4]

ENERGY HARVESTING II: PIEZO-BASED

1137606 A tapered beam piezoelectric energy harvester shunted to P-SSHI interface [11376-5]

1137608 An integrated design approach of piezoelectric vibration energy harvesters [11376-7]

1137609 Self-powered SECE-based piezoelectric energy harvesting for sensor supply under shock excitations [11376-8]

MODELING, OPTIMIZATION, AND DESIGN OF INTEGRATED SYSTEMS

$11376 \mathrm{OB} \quad$ Torsional loading analysis using cross-shaped piezoelectric sensor [11376-10]

11376 OD Design and experimental verification of a planar type two-dimensional piezoelectric actuator [11376-12]

$11376 \mathrm{OH} \quad$ Modeling the behavior of magnetorheological elastomers under different loading conditions [11376-16]

NEW INTEGRATED SYSTEMS

11376 OK Impact damage detection in composite plates using acoustic emission signal signature identification [1 1376-19]

MORPHING/DEPLOYABLE STRUCTURES

$11376 \mathrm{OL}$ The influence of geometry on origami's deployment dynamics [11376-89] 
11376 OM Aircraft morphing systems: elasticity of selected components and modelling issues [11376-20]

$1137600 \quad$ Kinematic analysis of a deployable truss structure with flat-form storability [11376-22]

SMART SENSING AND SIGNAL PROCESSING FOR DIAGNOSTICS AND PROGNOSTICS

$113760 Q$ Self-powered thin-film impedance spectroscopy sensor system to measure corrosion presence in aerogenerators or aircrafts [11376-25]

11376 OT Texture analysis using a piezoelectric actuator-sensor pair [1 1376-28]

11376 OV Impact localization on composite plates using two developed imaging methods [11376-30]

\section{MAGNETORHEOLOGICAL DEVICES AND SYSTEMS}

11376 OY Exploiting dynamic magnetic fields for new magnetorheological fluid damping capability [11376-33]

1137610 Test and analysis of MR mounting system for automotive engines [1 1376-35]

\section{ELECTRO-MECHANICAL METAMATERIALS}

1137612 An investigation of optimal non-uniform locally resonant piezoelectric metamaterials [11376-37]

1137613 Design and experimental analysis of nonreciprocal wave propagation in a space-time modulated beam [11376-38]

\section{FLIGHTS}

1137615 2D aerodynamic analysis of a badminton shuttle for re-entry vehicle applications [11376-41]

1137616 Insect-inspired micro air vehicle with nanocomposite flapping wings and flexure joints [11376-42]

1137617 Aerodynamic characteristics of the continuous twisting trailing edge [11376-43]

PASSIVE AND ACTIVE VIBRATION ISOLATION SYSTEMS I

11376 1C Towards a nonlinear buckled piezoelectric beam system for enhanced electromechanical energy conversion [11376-49]

iv 
ENERGY HARVESTING III: GENERAL

$11376 \mathrm{IF} \quad$ System prototype for a triboelectric harvester in a smart knee implant (SPIE Best Student Paper Finalist) [1 1376-52]

$113761 G$ A rotational impact energy harvester utilizing the centrifugal softening effect [11376-54]

$11376 \mathrm{1H}$ The transferring technique development of PZT thick film from silicon to flexible substrates [11376-55]

$1137611 \quad$ Power and electromechanical coupling of nonlinear piezoelectric vibration energy harvesters [11376-56]

METAMATERIAL AND STRUCTURES: WAVE CONTROL

$113761 \mathrm{M}$ Investigation of resonance enhancement through non-uniform piezoelectric polarization for information storage methodology [11376-59]

11376 iN Metamaterial-based amplification of multi-mode ultrasonic guided waves toward improved damage detection in pipelines (SPIE Best Student Paper Finalist) [1 1376-60]

\section{ENERGY HARVESTING AND TRANSFER}

11376 1T Verification of the flexoelectric effect in PET polymer films for EH applications [11376-66]

$113761 \mathrm{U}$ Exploring the magnetic plucking motion towards a transient-motion-powered loT sensor node [11376-67]

\section{PASSIVE AND ACTIVE VIBRATION ISOLATION SYSTEMS II}

1137612 Effect of negative capacitance circuits on the performance of the piezoelectric nonlinear energy sink [11376-74]

1137620 Experimental and numerical study on shock reduction on thin plate with elastic patch [11376-75]

1137621 Surrogate-based performance evaluation strategy for high performance control systems under uncertainties [11376-76]

$1137623 \quad$ Numerical investigation towards the control of flexural waves using structural intensity for an active barrier of structure-borne sound [11376-78] 
1137624 In-situ tunable auxeticity in pressurized soft mechanical metamaterials [11376-80]

1137625 Programmable single-layer polymer films for millimeter and sub-millimeter self-folding origami [11376-81]

1137626 Locally resonant mechanical dome metastructures for bandgap estimation [11376-84]

\section{POSTER SESSION}

1137628 Theoretical and experimental study on a piezoelectric linear motor driven by multi-integerfrequency multi-mode method [11376-86]

1137629 DC power and loss evaluation of an out-of-plane mode electret-based energy harvester [11376-87]

11376 2D Metamaterial inspired tensairity beam for frequency band attenuation [1 1376-92]

$113762 \mathrm{E}$ Transient snap-through of a bistable composite laminate under asymmetric point load [11376-93]

$113762 \mathrm{~F} \quad$ A novel approach for maximization of attenuation bandwidth of the piezo-embedded negative stiffness metamaterial [11376-95]

$113762 \mathrm{H} \quad$ A study on a Ferro-electret film-type speaker [11376-97]

$1137621 \quad$ Solution of inverse kinematic problem for serial robot based on screw theory [11376-98]

$113762 \mathrm{~K}$ Design and conception of a trailing edge morphing wing concept with bistable composite skin [11376-100]

$113762 \mathrm{M}$ A selective negative derivative feedback algorithm to improve stability for inertial actuators [11376-102]

$113762 \mathrm{U}$ Experimental verification of a self-excited power generation system for dielectric elastomer generation using piezoelectric elements [11376-1111] 